\title{
A Model of Causal Relationships Affecting the Effectiveness of Primary Schools under Khon Kaen Primary Education Service Area
}

\author{
Kantawan Sangsurin ${ }^{1}$, Asst.Prof.Dr.Prayuth Chusorn² ${ }^{2} \&$ Dr.Pha Agsonsua ${ }^{2}$ \\ ${ }^{1}$ Doctoral student in Educational Administration Program, Northeastern University, Thailand \\ ${ }^{2}$ Thesis adviser in Doctoral Program of Educational Administration, Northeastern University, Thailand \\ Correspondence: Asst.Prof.Dr.Prayuth Chusorn, Thesis adviser in Doctoral Program of Educational Administration, \\ Northeastern University, Thailand. E-mail: prayuth.chu@neu.ac.th
}

Received: November 4, 2019

Accepted: January 15, 2020

Online Published: January 16, 2020

doi:10.5430/ijhe.v9n1p230

URL: https://doi.org/10.5430/ijhe.v9n1p230

\begin{abstract}
The objectives of this research were 1) to examine the causal relationship model of factors affecting the effectiveness of primary schools which was developed through empirical data, 2) to study the factors that have direct, indirect and overall influence on the effectiveness of primary schools in Khon Kaen. The samples were 640 school administrators including teachers in Khon Kaen primary schools. The data were analyzed by program computer using the method of structural equation modeling (SEM). The research results indicated that the causal relationship model factors affecting the effectiveness of Khon Kaen primary schools consist of 5 latent variables or factors namely: 1) school vision, 2) academic leadership, 3) promotion of school climate and environment, 4) quality teaching, and 5) learned behavior of students. As for causal relationship model of factors affecting the effectiveness of the above-stated schools, it is found that the construct validity is in congruence with the empirical data. The indices of congruence are Chi-Square at $94.793, \mathrm{df}=87, \mathrm{P}-\mathrm{value}=0.2662, \mathrm{TLI}=0.998, \mathrm{CFI}=0.999, \mathrm{SRMR}=0.031$, RMSEA=0.013, with statistical significance at .01 . The factors that directly and positively affect were of statistical significance at .01 , are 1) shared vision, 2) academic leadership, 3) teaching quality, respectively, The most indirect influential factors affecting the school effectiveness are 1) shared vision, having indirect influence in positive manner to climate and environment of the schools, affecting in positive manner to teachers' teaching quality, and 3) academic leadership having indirect influence in positive manner on school climate and environment that affect students' learning, respectively.
\end{abstract}

Keywords: causal relationship model, factors affecting school effectiveness

\section{Introduction}

The Office of the Basic Education Commission is an organization that provides education by determining the development of education in accordance with the needs of the country, which the school is an organization whose main mission is to organize the teaching and learning so that students achieve the goals set in the curriculum of each level which considered as an important foundation for quality development of the population in the country. The most important factor is that administrators have a role and influence on the operation of the school which will lead the school to become a learning organization. In addition, students will be developed to their maximum potential with strong and appropriate knowledge and skills .Office of the Basic Education Commission set a policy including 1) Expedite basic education reform to have process improvements providing basic education for the whole system to be effective 2) Speeding up the development of educational strength for learners of all levels and types including children with disabilities and the opportunity to have knowledge and skills of the modern world together 3) Accelerate the adjustment of educational support systems that are in the same direction of coordination with the content, skills and teaching process 4) Enhance the strength of professional standards of teachers and school administrators, encoraging teachers to have abilities and skills 5) Accelerate the construction of the system for the Education Service Area Office to be a strong organization and of effective quality 6) Accelerate the improvement of the school to be a strong organization having a clear vision for basic education and able to provide quality teaching and learning 7) Establish a system for controlling the changes in education with information 8) Creating a new culture in the workplace. Accelerate the distribution of power and responsibility for improving the school system to be a co-thinking, co-operation, focusing on participation and coordination 9) Accelerate the human resource management system with focus on aptitude, accuracy, suitability, and fairness 10) Focus on creating good 
citizens who are alert and able to live with others in the multicultural society and enable education to solve important social problems 11) Create measures to improve the quality of schools, develop those lagging behind and small quality schools that are now losing students, and opportunity in education. (Office of the Basic Education Commission, 2015). The Secretariat of the Education Council has been following up and evaluating educational reform since 2009, there has been a problem that needs to be improved, developed and continued for the school's effectiveness. The most of them are schools in the northeastern region. (Secretariat of the Council of Education, 2009).

\section{Literature Reviews}

The effectiveness of the school is about the success of job performance. In addition, the indicators of school effectiveness are the ability to produce students with high academic achievement job satisfaction of teachers, professional development and teaching quality of teachers, and the ability to adjust and develop the school to suit the environment which is consistent with the concept of Mott (Mott, 1972). Dictionary of Merriam-webster (2001) defined that (1) the effectiveness is the sequent result from certitude decision, needs, readiness or tendency to create the quality or Competency Levels, (2) the effectiveness is the sequent result of process which was analyzed between the cost of production and (3) the proportion of energy usage which was worth on operating system as well as efficiency set. These definitions are accorded to the views of many educators, such as Cowan (1983) starting that the efficiency is the proportion between possible or ideal results, Gibson, Ivancevich and Donelly (2000) considered efficiency is the proportion between products and cost units on utmost product units which were considered some inputs as budget, man, material in regarding the efficiency is one component of effectiveness. Drucker Donelly (1983:cited Wirot Sanrattana, 2011) explained two key components of performance which are capability in resource utilization of transforming process to achieve organizational goals appropriately and completion (do the right things and goal attainment). Greenberg, Jefald (2004) defined that the effectiveness is the capability which drives missions for achieving goal and successful task as well as creating one result or more aligning with objectives. These results are the consequence from decision making and sequence performance which are aim setting, decision making on practice. Likewise, effectiveness is the result from organizational process or capability level to attain objective outcome. From the definition of various field educators had many variety of views such as the economists rather have focused on the quality or quantity of output, so effectiveness often be explained as a new invention amount of organization. While the social scientist have the views on the quality of life,etc. On the other hand, the educators have focus on the quality of education which is the quality of learner following curriculum goal. Reasonably, effectiveness is involved two key words of result achievements as outputs and outcomes, then the school effectiveness evaluation have to compare between objectives or goals and achievements based on aims or goals of school. Therefore, the leaders of organization desire to attain effectiveness of performance more than anything else.

In conclusion, the research author has a viewpoint on "effectiveness" as the success or objective and goal accomplishment of school on outputs and outcomes. The school effectiveness is the success indicator of school which are interested by administrative educators and people in general, then the author has presented as follows, Lunenburg; \& Ornstein. (2004) proposed the methods to consider whether or not the school effectiveness school by the school effectiveness principle as the achievements of student which were focus on two common indicators 1) comparing between the expected achievement and exist achievement of students, 2) analyzing the achievement of learners whether or not, income comparing the scores between the same kind of schools in term of the same social class and income of parents, 4) comparing the groups of student on gender and social class, 5) analyzing on most of high grade and kurtosis and skewness of achievement levels; furthermore, there are some criteria set to measure the school effectiveness as follows ;

1. Security, cleanliness and orderliness of school.

2. Understanding of school mission of all of teachers have involved and the organizational objective clearly known, task priority, measure and assessment process and collective responsibility.

3. Instructional Leadership of the principal who has to understand academic affairs and characteristics which are applied toward effectiveness tasks.

4. The good climate for personnel staffs with competency to lead students learning on the necessary skills.

5. The sufficient time for school missions as with as the time for student on activity planning and skill practice.

6. The frequenty examine on student progress as students are being developed and school children counseling and individual student assistance. 
7. The positive relationship between school and parents. Parents are encoraged to support the missions and school activity witch is consident very important.

Causal relationship model: Mongkut Chamnongnit (2013) studied the development of the causal relationship model of the factors influencing the academic administration effectiveness of small schools in the Northeastern region, Thailand which is summarized as follows ; 1) the causal relationship model of the factors influencing the academic administration effectiveness of small schools consisted of 6 latent variables and 29 indicators : 1) result variables is the academic administration effectiveness of small schools which consisted 4 indicators 2) exogenous latent variable - leadership of administrator with 5 indicators; instruction supervision, characteristic of role model, teacher competency enhancement, change agent and instruction, curriculum management 3) empowerment on effectiveness performance of teacher with 5 observable variables job satisfaction, teamwork, organizational relationship, collective responsibility and professional growth 4) employee motivation with 6 variables success opportunity creation, reward or compensation, good relationship making, job climate, capability acceptance, performance participation 5) learning process variables with 6 observable variables child-centred, thinking process, participation, variety activities, learning climate, integrated-learning management 6) ICT factors with 3 observable variables knowledge creation, management and ICT creative-utilization. The synthesis results on causal factors influencing the academic administration effectiveness of small schools in Khon Kaen Province was found that there were 17 components of theoretical framework. In this research process, the researcher used the criteria on frequency of components from 5 educators. views at and to select the component from the frequency at least 50 percentage of educator views. Then, there were 5 components for constanding the conceptual framework as 1) shared vision 2) academic leadership 3) school climate and environment improvement 4) quality of instruction and 5) student behaviors. The development of the causal relationship model is important in order to find the causal relationship which is direct factor affecting the effectiveness of the school are as follows: 1) shared vision, 2) academic leadership, 3) promoting the climate and environment in the school, 4) teacher teaching quality and 5) student behavior. The study of Phatthana Si Hanu (2010) about the causal relationship of factors affecting the effectiveness of small schools, found that the factors of direct influence on the effectiveness of the small schools are 4 factors which are earning process, management of organization, performance factors and learning organization and Supattara Wirawut (2011) studied factors affecting the effectiveness of primary schools under the Office of the Basic Education Commission In Nonthaburi, found that leadership factors of executives, participation of parents, desirable characteristics of students have a positive direct influence on school effectiveness, these factors directly and indirectly influence the school and can be used to predict the effectiveness.

\section{Research Objectives}

The researcher specified the research objectives as follows

1.To examine the causal relationship model of factors affecting the effectiveness of primary schools in Khon Kaen Province with empirical data

2.To study factors which have direct, indirect, and overall influence on the effectiveness of primary schools

\section{Research Methodology}

The population used in this research were school administrators and teachers in primary school of Khon Kaen Province, academic year 2018. The sample group consisted of 640 people, consisting of the school administrators and primary school teachers. Sample size that is suitable for data analysis using MPlus program by using the structural equation modeling (SEM) technique according to Hair et al. (1995, quoted in Theerawat Suksan, 2011) suggesting that the appropriate sample size is 200-300 samples and Comrey \& Lee (1992); Hair et al (2010 quoted in Thanin Sinj Jaru, 2012) had suggested the sample size should be 10-20 times the number of observation variables in the research itself. In This research has 21 observable variables. The suitable and sufficient sample size should be at least 10 times x 21 observation variables equal to 210 samples up to 20 times x 21 observable variables equal 420 samples. The calculated result was the minimum sample size that can be used for analysis of the structural equation model (SEM).

The instrument used in this research was a 5 level rating scale questionnaire. Data were analyzed by program computer using the method of structural equation modeling (SEM). Basic statistics are mean and standard deviations for analysis of the consistency of the model, relationship of the theoretical factors and empirical data by the Path Analysis method, determined by the Goodness of Fit Measures. 


\section{Research Result}

The causal relationship model factors affecting the effectiveness of Khon Kaen primary schools consists of 5 latent variables or factors namely 1) school vision, 2) academic leadership, 3) promotion of school climate and environment, 4) quality teaching, and 5) learned behavior of students. As for causal relationship model of factors affecting the effectiveness of the above-stated schools, it is found that the construct validity is in congruence with the empirical data. The indices of congruence are Chi-Square at 94.793, $\mathrm{df}=87, \mathrm{P}$-value $=0.2662$, TLI $=0.998$, $\mathrm{CFI}=0.999, \mathrm{SRMR}=0.031, \mathrm{RMSEA}=0.013$, with statistical significance at 01 . The factors that directly and positively affect with statistical significance at .01 are 1) shared vision, 2) academic leadership, 3) teaching quality, respectively, The most indirect influential factors affecting the school effectiveness are 1) shared vision having indirect influence in positive manner to climate and environment of the schools affecting in positive manner to teachers' teaching quality, and 3) academic leadership having indirect influence in positive manner on school climate and environment that affect students' learning, respectively, as shown in Figure 1.

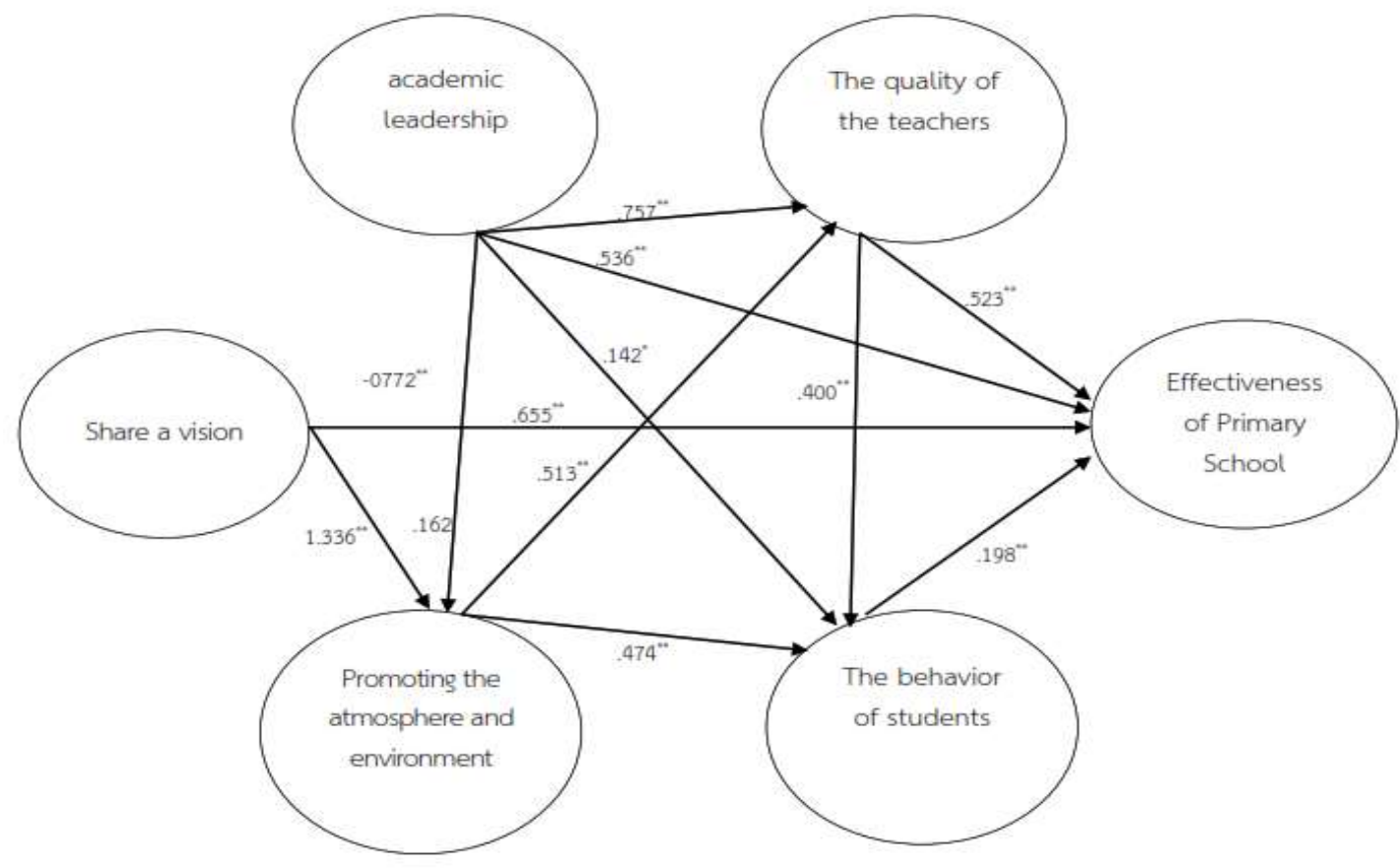

Chi-Square $=94.793, \quad \mathrm{df}=87, \quad \mathrm{P}$-value $=0.2662, \mathrm{TLI}=0.998, \quad \mathrm{CFI}=0.999$, SRMR $=0.031, \quad$ RMSEA $=0.013$

Figure 1. shows the relationship between the causal structure of the administrative factors affecting the effectiveness of Khon Kaen Primary School 
The influence of variable loading to form the causal structure of the administrative factors affecting the effectiveness of Khon Kaen Primary School as in the table 1.

\begin{tabular}{|c|c|c|c|c|}
\hline & Effect & $\mathrm{DE}$ & IE & TE \\
\hline & SHS to EFFE & $0.655^{* *}$ & - & $0.655^{* *}$ \\
\hline & ACL to EFFE & $0.536^{* *}$ & - & $0.536 * *$ \\
\hline & TEA to EFFE & $0.523 * *$ & - & $0.523 * *$ \\
\hline & LER to EFFE & $0.198^{* *}$ & - & $0.198 * *$ \\
\hline \multicolumn{5}{|c|}{ Direct effect from Latent Variable: } \\
\hline & SHS to ENV & $1.336^{* *}$ & - & $1.336 * *$ \\
\hline & ACL to ENV & $0.162 * *$ & - & $0.162 * *$ \\
\hline & ACL to TEA & $0.757 * *$ & - & $0.757 * *$ \\
\hline & ACL to LER & $0.142 *$ & - & $0.142 *$ \\
\hline & ENV to TEA & $0.513 * *$ & - & $0.513 * *$ \\
\hline & ENV to LER & $0.474 * *$ & - & $0.474 * *$ \\
\hline & TEA to LER & $0.400 * *$ & - & $0.400 * *$ \\
\hline \multicolumn{5}{|c|}{ Indirect effect from Latent Variable: } \\
\hline & SHS to ENV to LER to EFFE & - & $2.008 * *$ & $2.008 * *$ \\
\hline & ACL to LER to EFFE & - & $0.34 * *$ & $0.34 * *$ \\
\hline & ACL to TEA to EFFE & - & $1.28 * *$ & $1.28 * *$ \\
\hline & ACL to ENV to LER to EFFE & - & $0.834 * *$ & $0.834 * *$ \\
\hline \multicolumn{2}{|r|}{ TEA to LER to EFFE } & - & $0.598 * *$ & $0.598 * *$ \\
\hline $\begin{array}{l}\text { Chi-Square } \\
\text { RMSEA = }\end{array}$ & $\begin{array}{l}=94.793, \quad \text { df }=87, \quad \text { P-value }= \\
0.013\end{array}$ & \multicolumn{3}{|c|}{$\mathrm{CFI}=0.999, \mathrm{SRMR}=0.031$} \\
\hline
\end{tabular}

\section{Summary and Discussion}

Results of variable studies of the effectiveness of Khon Kaen primary schools consists of 4 variables or factors namely 1) ability to produce students with high student achievement, 2) job satisfaction of teachers, 3) professional development and teaching quality of the teachers and 4) ability to adapt and develop schools to match the environment Mott (Mott, 1972) discussed the effectiveness of school consisting of 4 abilities which are ability to produce students with high academic achievement, ability to develop students to have a positive attitude, problem solving ability in schools and the ability to change and develop schools and also in consonant with the research of Anukul Srisombat (2013). the studied the model of the causal relationship of the multilevel factors affecting the effectiveness of school which were the ability to produce students with high academic achievement, the ability to adjust and develop the school, the ability to develop students to be good people and have a positive attitude, professional development and quality of personnel, and job satisfaction. Shared vision can be measured from 4 observable variables which are 1) creating vision, 2) articulating and explaining vision, 3) observing vision, and 4)being a good model. Shared vision (SHS) has a direct positive influence on the effectiveness of the school The shared vision also has a positive indirect influence on the effectiveness of the school through the promotion of the climate and environment in school (ENV) through the student's behavior (LER) in aligning with assumptions.

Academic leadership factors can be measured from 3 observable variables which are 1) personnel development according to their roles, 2) stimulating intelligence 3) promoting the academic learning climate. Academic Leadership (ACL) has the second direct influence and effectiveness of school performance. In addition, there are 3 indirect influences: 1) academic leadership (ACL) also has positive indirect influence through student learning behavior (LER) 2) academic leadership (ACL) has positive indirect influences through teacher quality of teaching (TEA) and 3) academic leadership (ACL) has positive indirect influences through the promotion of school atmosphere and environment (ENV) through learned behavior. Learning of student (LER) is consistent with the hypothesis that explains a feature that the leadership of the party was committed and dedicated to the members to work in line with the vision of the organization and coordinate the vision of the person to create job, teach skills as 
well as being a helper to support the implementation of the organization's goals. It is also found that leadership has indirect influence through motivation, culture, mission and strategy, including organizational structure because the current executives must have academic leadership, encourage teachers to use teaching innovation, be a good role model in academic support and academic excellence of the school. Promote teaching-learning management that is of student-centered and supervision of teaching and learning to be in accordance with the specified teaching plan, which is in line with the educational reform guidelines from the educational reform that has resulted in schools nationwide to reform the learning process according to Article 24 of the National Education Act 1999, requiring schools to organize content and activities. In accordance with the interests aptitude of learners practice skills in thinking processes, management, coping, and applying knowledge to prevent and solve problems Organize activities for learners to learn from real experience. Arrange teaching and learning by blending various knowledge Promote and support teachers to create an climate, environment, media, and facilitate the learners to learn including learning to occur at any time and every place consistent with the research of Samrit Kangpeng (2008) and in accordance with Supattra Wirawut's (2012), Pramook Chusorn. (2018).

The quality of teaching factors can be measured from 4 observable variables which are 1) organize various learning processes 2) learners participate in the learning process 3 ) focus on thinking processes 4) developing positive attitude for students. There is direct influence on school effectiveness, having a positive indirect influence through student learning behavior (LER) consistent with the research of Somchit Udom (2004), studying the factors affecting the success of the administration of private elementary schools in the southern region, found that teaching quality of teachers affect academic achievement and also affect school administration.

Student behavioral factors can be measured from 3 observable variables which are 1) attention to the lesson, 2) enthusiasm and 3) interested in learning. There is a direct positive influence on the effectiveness of the school without indirect influence in accordance with the hypothesis be explain that the student's learning behavior demonstrates the characteristics of the students that demonstrate attention to the lesson enthusiasm interested in learning, determination and being able to know planning and learning methods while studying. Consistent with the research of Anukul Srisombat (2013), studying the model of the causal relationship of the multilevel level factors affecting the effectiveness of the school Loei Educational Service Area Office, Area 2. The results of the analysis of the influence of multilevel causal factors on school effectiveness found that at the personal level, the influential factors overall, the highest school effectiveness was the teacher learning process behavior (0.64), student behavior (0.61), classroom atmosphere (0.46), and the sense of belonging to the organization $(0.23)$.

Policy Recommendation

1) Education area administrators can utilize the results of research to determine a policy on school effectiveness development.

2) School administrators can utilize the results of research to set direction, process, strategy and strategic for improving school effective to more efficiency.

3) The research results found that factors were most affected directly and indirectly to school effectiveness of primary school as shared vision, academic leadership, behavior of teacher, behavior of student, school climate and environment orderly. Thus, the administrators should determine direction policy and strategic on factors development corresponding to condition, problems, emphasis points continuously.

Practical Recommendation

The research results found that the effectiveness of primary school in Khon Kaen province which were arrange in descending order as production competency, high learning achievement of student, reforming and developing competency toward environment, instruction quality and profession development of teacher and job satisfaction of teacher. Therefore, education area office and schools are the operating unit which have to consider the information and improve some weakness as job satisfaction of teacher practically.

\section{Research Recommendation}

1) This research study only the sample of primary school in Khon Kaen province. It will be more benefit if research are processed on managerial factors affecting school effectiveness in primary school in term of multi-level study which collect data from the samples of all primary school in Thailand to find out the guideline of causal relationship factors influencing school effectiveness extensively.

2) After developing the model, case study method is very benefit and useful to develop the managerial factors and then compare results and find out suitable and possible guideline. 
3) A developing model can be apply to study on bench-marking both public and privacy educational institutes which is the development model of causal relationship managerial factors influencing the effectiveness of high quality schools continually.

4) Furthermore, a research should be study on the relation between factors affecting learning organization in basic education school such as action research or research and development in the future.

\section{References}

Anukun Srisombat. (2013). Studied the model of the causal relationship of the multilevel level Of the factors that influence School effectiveness Office of Loei Primary Education Service Area. Graduate Program in Educational Administration Northeastern University.

Donelly, \& Ivancevich. (2000). Fundamentals of Management. Front Cover. McGraw-Hill College.

Jefald Greenberg. (2004). Managing Behavior in Organizations. Prentice Hall PTR.

Hair, J., et al. (2010). Multivariate data analysis (7th ed.). Upper saddleiver, new jersey: Pearson Education International. https://doi.org/10.1016/j.jmva.2009.12.014

Hoy, W. K., \& Miskel, C. G. (2008). Educational administration: Theory, research, and Practice. 8th ed. New York: McGraw-Hill.

Lunenburg, F.C., \& Ornstein, A. C. (2004). Educational Administration Concepts and Practices. Newyork : Thomson Learning, Inc.

Merriam-Webster's Collegiate Dictionary. (2001). Springfield. (10th ed.). MA: Merriam-Webster.

Mott, R. M. (1972). The character of effective organization. New York: Harper and Row.

Mongkut Chamnongnit. (2013). Studied the development of the causal relationship model of the factors influencing the effectiveness academic administration of small schools in the northeastern region Thailand. Graduate Program in Educational Administration Northeastern University.

Office of the Basic Education Commission. (2015). Policy, Minister of Education Bangkok: Office of the Permanent Secretary Ministry of Education.

Phatthana Sihanu. (2010). The Causal Relationship Model of Factors Influencing School Effectiveness under the Office of Educational Service Area in the region northeast. Department of Educational Administration, Loei Rajabhat University.

Pramook Chusorn. (2018). Leadership Competency Development for Administrators. 6(22). January - March 2018. JOURNAL OF EDUCATIONAL ADMINISTRATION AND LEADERSHIP SAKHON NAKHON RAJABHAT UNIVERSITY.

Samrit Kangpeng. (2008). Administrative Factors Affecting School Effectiveness: Model Development and Validation. Doctor of Education Program Graduate School, Khonkaen University.

Sanrattana, Wirot. (2011). Educational Management Research: Approach and Case Study. 2ndEd. Bangkok: Aksarapipat.

Saowalak Somatat. (2010). The relationship between transformational leadership of female administrators and effectiveness of the school under the Educational Service Area. Department of Educational Administration, Burapa University.

Somchit Udom. (2004). Factors Affecting the Success of Private Primary School Administration in Southern Thailand. Department of Educational Administration, Chulalongkorn University.

Suphattra Wirawut (2011). Factors Influencing the Effectiveness of Primary Schools. Under the office of the Commission Basic education in Nonthaburi province. Doctoral thesis, Wongchawalitkun University.

Varopeng Sawat. (2006). Developing a linear structural relationship model of leadership effectiveness of Administrators Affecting School Effectiveness. Doctor of Education Program Graduate School, Khonkaen University. 